\title{
Szabó Lajos: A szociálisszervező-képzés szerepe a hazai idősellátás alakulásában
}

(Visszatekintés a szociálisszervezö-képzés születésének 45. évfordulóján)

E visszatekintés - hasonlóan Hegyesi Gábor „Emlékek a szociális munka születésének társadalomtörténetéről” címen megjelent tanulmányához (Hegyesi 2018) - személyes emlékeim nyomán született a szakmai életutam egy meghatározó szakaszához kapcsolódva, így emiatt nem tekinthető e képzés története elfogulatlan bemutatásának. Egy objektív és részletes történeti feldolgozással a szakma adós maradt, és egyre inkább elvész annak az esélye, hogy valaha is megszülessen. Ennek egyik oka az, hogy a költözések során a képzési dokumentumok, tanszéki anyagok jórészt elkeveredtek, másrészt az, hogy a képzést létrehozó és alakító oktatók közül többen már nincsenek köztünk vagy visszavonultak, és a képzésben diplomát szerző szociális szervezők jelentős része is már nyugdíjba vonult. E képzés megálmodója dr. Göllesz Viktor főiskolai tanár - a Bárczi Gusztáv Gyógypedagógiai Főiskola volt föigazgatója - már sok éve nincs köztünk, és a képzés kialakításában tanszékvezetőként meghatározó szerepet játszó Kemény Ferenc főiskolai docens, valamint kulcsszerepet játszó munkatársaink - köztük az idősellátás oktatásában fontos szerepet játszó Sáhó Erzsébet főiskolai adjunktus is - már visszavonultak, így a korábbi „belső stáb” utolsó aktívan oktató tagjaként kötelességemnek érzem, hogy ezen évforduló kapcsán felidézzem e képzést, és emlékeztessek annak a több száz szakembernek a munkájára, akiknek ez a képzés adott szakmai képesítést, és akik évtizedekig szolgáltak tisztességgel a szociális ellátórendszerben, ezen belül nagy arányban az idősellátás területén.

Túl az emlékezésen e tanulmánynak fontos eleme az is, hogy választ keressek arra, hogy milyen tényezők játszottak szerepet a hazai idősellátás alakulásában. Ez a kérdés szorosan kapcsolódik a szociálisszervező-képzés szerepéhez a hazai idősellátás területén.

Amikor Göllesz Viktor a hazai gyógypedagógia egyik legmeghatározóbb és legelkötelezettebb egyéniségeként e képzés létrehozását kezdeményezte, kilépve a gyógypedagógia tradicionális oktatási-nevelési keretei közül, figyelmét a fogyatékossággal élő felnőttek intézményi ellátása és rehabilitációja felé fordítva egy olyan szociális szakemberképzés kereteit vázolta fel, amelynek középpontjában a fogyatékkal élők életviteli támogatása állt. A képzés elindításáért folyó minisztériumi egyezkedések során a képzés 
kiterjesztése az idősellátás területén dolgozók képzésére az eredeti elképzelésen túllépve „kapcsolt áruként” jelent meg egy alkufolyamatban. Én évekkel később csatlakozva a képzéshez, gyógypedagógus-végzettségem ellenére - miután más területeken dolgoztam -, nem vagyok megfelelően felkészült arra, hogy a szociálisszervező-képzés szerepét és hatását a fogyatékossági területek oldaláról megítéljem, de visszatekintve a kezdetekre azt gondolom, hogy a képzés felépítése és elindítása időszakában sem Göllesz Viktor, sem pedig Kemény Ferenc nem sejthették azt, hogy e képzés hatása hosszú távon a hazai idősellátás alakulására lesz a legjelentősebb, és azt sem, hogy a képzésben részt vevők és diplomát szerzők legnagyobb arányban az idősellátás területéről érkeznek.

Kevésbé ismert körülmény az, hogy 1987-ben a szociálisszervező-képzés belső reformja kapcsán a gyógypedagógus-képzés szakosodási rendszerének mintájára kísérlet történt egy mentálhigiénés szakirány elindítására, és klinikai pszichológusként közel húsz év pszichiátriai ellátásban eltöltött év gyakorlati és oktatási tapasztalata nyomán e szakirány felépítésében kaptam szerepet olyan kiemelkedő szakemberek részvétele mellett mint Buda Béla, Andorka Rudolf és Ozsváth Károly. Ez a szakirány - elindítását követően - a szociális képzések átalakulásának sodrában rövid életü volt, és kritikusan visszanézve ma úgy gondolom, hogy egy túl korai és koncepcionálisan még nem kiérlelt képzési vállalkozásként jelent meg szociálpszichiátriai szempontból elégtelen hátterekkel (a mögötte meghúzódó szándék igazából a pszichiátriai betegek számára létrehozott szakosított otthonok stábjának szakmai képzése volt).

\section{A képzési igények megjelenése az idősellátás területén}

A hazai idősellátás alakulásának sorsát hosszú távon meghatározta az állami gondoskodás kiterjesztése az ötvenes években a tartós bentlakásos otthoni elhelyezést nyújtó intézmények számának gyors növelésével. Ezt a növekedést ingatlan kisajátításokkal lehetett elérni, úgy, hogy nagy számban alakítottak ki kastélyokban, kúriákban idősotthonokat. Ezek az intézmények strukturálisan gyakran nem megfelelő, nehezen alakítható, nagy hálótermeket magukba foglaló korszerütlen épületekkel működtek, sokszor közlekedésileg is nehezen elérhető, izolált helyzetben. A gondozó stábok egyrészt környékbeli szakképzetlen nőkből, másrészt az egészségügyi rendszerből átlépő nővérekből verbuválódtak, az intézményvezetők jelentős része pedig gazdasági-pénzügyi szakember volt, sokszor magasabb végzettség nélkül. $\mathrm{Az}$ intézmény szakmai müködését tartalmilag rendszerint középfokú egészségügyi elöképzettséggel és tapasztalattal rendelkező főnővérek alakították az egészségügyi 
rendszerben kialakult müködési-szervezési elvek mentén. Az egész rendszer szakmai felügyeletét tekintve az egészségügy perifériáján helyezkedett el, szakmai kultúráját pedig messzemenően meghatározták a vezetők személyes kvalitásai, törekvései, motivációi.

Ebből a helyzetből kiutat és elörelépést keresve a hatvanas évek második felében az akkori Egészségügyi Minisztérium Szociálpolitikai Főosztálya ösztönzésére létrejött egy módszertani intézmény Szociális Intézetek Központja néven, amelyben irányelveket, útmutatót dolgoztak ki a szociális otthonok müködéséhez, és elkezdődött az intézményvezetők képzése egy felkészítő tanfolyam keretében. E változásokban meghatározó szerepet játszott Hun Nándornak a szociálgerontológia terén kibontakozó munkássága, kutatásai és két kiadást megért „Bevezetés a szociálgerontológiába” című úttörő munkája (Hun 1972; 1978). Az ő munkásságának hatására alakult meg a szociális otthonok Hungária körúti ambulanciája és vizsgálóállomása, amelynek keretében a korai hazai geriátria bentlakásos otthoni idősellátással foglalkozó munkacsoportja tevékenykedett. Ez a munkacsoport alapozta meg az idősotthonokban folyó orvosi ellátás gyakorlatát olyan fóállást betöltő és egész szakmai életútjukat az idősellátásnak szentelő geriáterekkel mint dr. Hidvégi Katalin és dr. Keveházi Ferenc főorvosok, és innen, ill. a Szociális Intézetek Központjából érkeztek az 1973-ban létrejövő szociálisszervező-képzés keretében megjelenő idősellátási tárgyak oktatói: dr. Villányi Piroska és Sáhó Erzsébet, majd dr. Hidvégi Katalin. A következő évek során ők meghatározó szerepet játszottak a képzésben, és ők írták a képzés első tananyagait - köztük Villányi Piroska a szociális gerontológia első hazai tankönyvét, Sáhó Erzsébet pedig az idősellátás gyakorlatának kialakításában fontos szerepet játszó „Szociális gondozás” címü munkáját (Villányi 1978; Sáhó 1993).

Ha a szociálisszervező-képzés létrejöttének jelentőségét próbáljuk felmérni, akkor azt emelhetjük ki, hogy a szociális ellátás területén utat nyitott a felsőfokú képzések számára, és munka melletti képzésként lehetőséget biztosított a már az ellátás gyakorlatában tapasztalatokat szerzett és a szociális ellátás iránt elkötelezett munkatársaknak egy magasabb szakmai képzettségi szint megszerzésére. Ez az idősellátás területén különösen fontos volt, és jelentősen hozzájárult e terület szakmai fejlődéséhez.

\section{A szociálisszervező-képzés erősségei és gyenge pontjai}

1987-ben a pszichiátriai ellátórendszer gyakorlati terepein eltöltött éveket követően egy gyors váltás során kerültem a szociálisszervező-képzésbe. Pszichológusként arra készültem, hogy pszichológiai tárgyakat kell oktatnom és a mentálhigiénés szakirány kialakításában kell részt vennem. A szociális ellátórendszert csak érintőlegesen ismertem, és a szociális munkáról csak 
egy rövid külföldi szakmai úton szerzett ismeretekkel rendelkeztem. Mindezek ellenére elég hamar otthon éreztem magam. Ez nemcsak azért volt, mert Göllesz Viktor korábban tanárom volt, Kemény Ferenc pedig a gyógypedagógus-, majd a pszichológusképzésben évfolyamtársam volt, később pedig sok éven keresztül közös munkában és barátságban zajlott az életünk. Amellett, hogy terepröl érkeztem, a kezdetektől volt oktatási tapasztalatom részben oktató kórházból az orvostanhallgatók képzése során, részben pedig egészségügyi szakiskolából, ahol ápolónők képzésében ápoláslélektant tanítottam. A szociálisszervezőképzésbe bekerülők többsége egészségügyi terepről került a szociális ellátórendszerbe, hasonló képzésekben vett részt korábban, mint amilyenben tanítottam, és sok gyakorlati tapasztalattal érkezett. Azontúl, hogy értettem őket és alkalmazkodni tudtam előzetes tudásszintjükhöz, megragadott lelkesedésük és tanulási szándékuk. Az esély, hogy „első generációs értelmiségiként” új szakmai perspektívát találjanak, nagy hajtóerő volt számukra, és felidézte saját élményeimet, amikor a családomból elsőként tanultam főiskolán, majd egyetemen nappali és levelező képzésben egyaránt, „első generációs értelmiségivé” válva. A képzés légköre, szellemisége nagyon támogató volt, és „talajközeli” szemléletével erős szálakkal kötődött a szociális ellátás terepeihez és gyakorlatához. Az intézmények és a tanszék kapcsolata szoros volt, és sok éven keresztül természetes és kölcsönös szolidaritás kötött össze minket tanítványainkkal.

A képzés alakításában a mintát a gyógypedagógus-képzés $2+2$ típusú rendszere adta (két év alapra ráépülő szakirányok kidolgozásával). A képzés tantárgystruktúrája is sok elemében követte a gyógypedagógus-képzésben szereplő alapozótárgyak felépítését az anatómia, egészségügyi alapismeretek, fogyatékossági és geriátriai ismeretek, pszichiátria, ápoláslélektan alapjainak oktatásával. Ez egészült ki jogi és szociálpolitikai ismeretekkel, felnőtt fogyatékosok rehabilitációjával, szociális gerontológiával és szociális gondozási ismeretekkel. A változások sodrában ez a modell már nem tudott a maga teljességében felépülni, kibontakozni, és nem sok esély volt a nappali képzés beindítására sem. Visszatekintve erre a korszakra, ma talán a képzés erényének és legnagyobb értékének azt tartom, hogy utat nyitott egy szakmai generáció fejlődése számára, mintát nyújtott értékorientációban, elköteleződésben a sérülékeny klienscsoportok segítése terén, és különösen az idősellátás területén hozzájárult az ellátórendszer továbbépítéséhez és megerősítéséhez. Később azt is láthattuk, hogy erős indítást és motivációt adott a szakmai ismeretek továbbépítéséhez is (az általam ismert szociális szervezők többsége tovább kereste a tanulási lehetőségeket különböző szociális és államigazgatási képzésekben). 
A képzés gyenge pontjait tekintve elsőként a képzés izolálódását, felsőoktatási kapcsolódásainak hiányát emelném ki a hazai és a nemzetközi kapcsolatok vonatkozásában egyaránt. Ez nagyban megnehezítette a képzés megerősödését, általános elfogadását, és gyengítette „diplomáciai” helyzetét. Talán nem túlzás azt is mondanom, hogy a szociálisszervező-képzés sok éven keresztül a Bárczin belül is „,idegen test” maradt. Nagyon meghatározó volt az is, ahogy a képzés az „akadémikus világot” meglehetős távolságtartással szemlélte és kezelte, hangsúlyozva a gyakorlatközeliség jelentőségét, kevés erőfeszítést téve az elméleti hátterek megerösítésére. Ez megmutatkozott a szélesebb nemzetközi kitekintés és a társadalomtudományi alapvetés hiányosságaiban is. Ennek kapcsán szoktak arra hivatkozni, hogy a szociálisszervező-képzés kialakításának idején a hazai társadalomtudományok és a szociális ellátások terén - különösen a gerontológia és az idősellátás elméleti háttereinek ismeretében - jelentős lemaradás volt tapasztalható. Ezen tünődve, ha leveszem a könyvespolcról Hun Nándor „Bevezetés a szociálgerontológiába” címü könyvének 1972-es kiadását, rácsodálkozhatom arra az átfogó és korszerű nemzetközi kitekintéssel rendelkező ismeretanyagra, amely Hun Nádor akkori munkájában fellelhető. Gondolatai ma is elevenen hathatnak és iránymutatóak. Jó példa erre az, ahogy a szociális munkások helye, szerepe kapcsán könyve 282. oldalán ír. Az alábbiakat olvashatjuk:

„A social worker korunk újtípusú, nagy felkészültséget igénylő foglalkozása. Szemben a régi szociálpolitikai tisztviselővel, aki elsősorban adminisztratív feladatokat látott el (segélyeket osztott munkanélkülieknek, hadirokkantaknak, stb.), a mostani social workernek bonyolult és magas szintű feladatokat kell megoldania."

Talán érdemes lenne e sorokat a szociális munkások mozgásterét, munkáját nagyban meghatározó felelős minisztériumi tisztségviselők figyelmébe ajánlani. Azt is el kell mondanunk, hogy Hun Nándor könyvének 1978-as kiadásában már utal a szociálisszervezőképzés létrejöttére és Villányi Piroska „Szociális gerontológia” című tankönyvére. Felidézve a „social worker” tevékenysége kapcsán korábban leírt és itt idézett véleményét, azt egy finom kritikai megjegyzéssel egészítette ki (Hun N. könyvének 1978-as kiadása 468. oldalán), amely szerint „az oktatásnak korszerübbé tételére feltétlenül szükség van”. Kétségtelenül ez a megjegyzése a szociálisszervező-képzésre vonatkozott. Értve és elfogadva Hun Nándor akkori álláspontját, egy fontos körülményre kell azonban ennek kapcsán utalnunk: arra, hogy a szociálisszervező-képzés felépítése során felnőtt képzésben járatos oktatókként a gyakorlat talajáról, a képzésben részt vevők szintjéhez és tapasztalatához illeszkedő ismereti bázisról, fokról fokra haladva alakítottuk ki egy gyakorlatorientált képzés anyagát a tradicionális 
főiskolai képzési struktúrához kapcsolva, miközben előkészítettük a képzési szakirányok mentén bővülö ismeretek bevezetését. Ez a megközelítés azt a realitást képviselte, amely mentén egy gyakorlati mesterségre munka melletti képzés keretében próbáltuk felkészíteni a hallgatókat egy olyan felsőoktatási rendszerben, ahol hiányzott a képzési szintek átjárhatósága. Ez a feltételrendszer jelentősen eltért a Hun Nándor által is idézett kétlépcsős angolszász típusú szociálismunkás-képzések rendszerétől. Sokan nem értve ezt a képzési logikát, amelyet jelentős mértékben a gyógypedagógus-képzés tapasztalatai is megerősítettek, a szociálisszervező-képzést egyszerüen valamiféle alacsony szintü tanfolyamos képzésnek tekintették, és később a képzésimodell-váltás nyomán vitatták e képzés és a szociálismunkásképzés jogszabályi keretek között is megfogalmazott ekvivalenciáját, amely kapcsán sok esetben alkalmazási-besorolási viták bontakoztak ki.

Mindazonáltal a nyolcvanas évek közepétől a képzésimodell-váltás folyamata felgyorsult a szociális képzések korszerüsítése mentén. Ez egy bonyolult és feszültségekkel, konfliktusokkal is terhes időszak volt, amelynek lezárása szükségszerüen a szociális képzések átalakulásához és egyben a szociálisszervező-képzés megszünéséhez vezetett. Ennek kapcsán fontosnak tartom annak hangsúlyozását, hogy nem szándékozom e tanulmányban az átalakuláshoz kapcsolódó vitákat, konfliktusokat feléleszteni, és hiszem azt, hogy az abban résztvevők az azt követő évek közös munkája, erőfeszítései során ezeket már rég maguk mögött hagyták. Azt tudom csak megerősíteni, hogy az átalakulás résztvevőiként szinte kivétel nélkül valamennyiünknek voltak tévedései és igazságai. Nehéz időszak volt, amire visszatekintve hálás szívvel és elismeréssel gondolok vissza az átalakulás időszakának tanszékvezetőjére, Aczél Annára, aki türelmével és emberségével átsegített minket e korszakon, és képes volt egy közös stábot felépíteni. Az elismerés a korábbi tanszékvezetőnek - Kemény Ferencnek - is szól, aki önzetlenül segítette egy új tanszéki közösség kialakulását. Ma valamennyien, akik dolgozhattunk velük megbecsüléssel és őszinte barátsággal gondolunk rájuk.

Mindezt nagyon fontos volt elmondanom, mert a képzésimodell-váltás, átalakulás hatását tárgyalva az idősellátás sorsának alakulása kapcsán jelentős következményekkel kellett szembenéznünk, amelyek sok vonatkozásban kedvezőtlennek tekinthetők, ugyanakkor nem szeretném, ha ezzel kapcsolatos véleményemet az olvasók félreértenék, és elfogultságom számlájára írnák. 


\section{A képzésimodell-váltás hatása az idősellátás alakulására}

A szociális képzések kibontakozása és az a képzésimodell-váltás, amely egy modern, angolszász típusú szociálismunkás-képzés hazai megjelenéséhez vezetett, szorosan kapcsolódott azokhoz a társadalmi folyamatokhoz, amelyek a rendszerváltás sodrában a változások nyomán megjelenő új kihívások mentén alakították a képzés és a szociális munka gyakorlatának arculatát, súlypontjait. Ez egy ambiciózus és lelkes program volt, amelyhez jól illeszkedett a hetvenes évek amerikai szociális munkájából átjövő progresszív szemlélet és társadalmi érzékenység, valamint a hazai változások lendületének, várakozásainak találkozása (erre visszanézve - lehet hogy tévesen - mindig az a gondolatom támad, hogy a „közvetítők”, akik a hetvenes években szakmai pályájuk legszebb éveit élték meg, a nyolcvanas évek öket érintő kedvezőtlen változásai nyomán valamiféle értékmentés keretében próbálták átadni nekünk a szociális munka egy korábban sikeres és igényes modelljét). A hazai törekvések középpontjában egy egységes képzési rendszer kialakítása állt közös erőfeszítések és konszenzuskeresés mentén (ennek dokumentuma a soproni konferencia anyaga, amelyre Hegyesi Gábor is utal tanulmányában). Világosan látható volt az, hogy ez az egységes képzési rendszer leginkább egy „általános szociálismunkás-képzés” keretei között valósítható meg (ez egyben a szakirányok felé építkező tartalmi és érdekkülönbségek háttérbe szorítását hozta magával). Egy másik fontos törekvés a szociálismunkás-képzések megerősítése volt a nappali képzés előtérbe helyezésével. E nélkül nehezen lett volna elképzelhető a szociálismunkásképzés megkapaszkodása és presztízsének megerősítése a felsőoktatás rendszerében (a következménye ennek ugyanakkor a munka melletti képzések nagymértékü háttérbe szorulása volt). Kiemelkedő jelentőséggel bírt a szociálismunkás-képzés társadalomtudományi-elméleti megalapozása is. Ehhez kapcsolódott a társadalmi kihívásokra választ kereső képzési és ellátásfejlesztési törekvések előtérbe kerülése. Ennek nyomán a hazai szociális munka érdeklődésének előterébe kerültek a társadalmi marginalizáció, hajléktalanság, munkanélkülivé válás, a sokproblémás családok nehézségeinek problémái és a családsegítés, gyermekvédelem, hajléktalan-ellátás, drogprevenció terén megjelenő új szolgáltatások, a közösségi szociális munka, valamint a makroszintü folyamatok - a szociálpolitika és a szociális munka kapcsolatának kérdése - és még hosszan bővíthetnénk e felsorolást.

Ha végiggondoljuk a változásokat és a preferált témákat, akkor azt láthatjuk, hogy a szakmai építkezés lendületében az idősellátás meglehetősen háttérbe szorult. Ennek kapcsán elmondható az is, hogy a nappali képzésben részt vevő hallgatóknak csak egy igen kis hányada érdeklődött az idősellátás iránt, ugyanakkor a munka melletti képzések beszükítése 
nagyban megnehezítette az idősellátás számára a szakember-utánpótlást és a terepről „felmozgás” lehetőségeit, az általános szociális képzés” által kínált tananyag pedig kevés segítséget adott az idősellátás iránt érdeklődők megfelelő felkészítéséhez. Az is elmondható, hogy a képzőhelyek részéről sem mutatkozott jelentős érdeklődés e terület iránt, és szellemi invesztációjuk e téren ezekben az években elég szerény volt (a kivételt a nyíregyházi képzés jelentette, amely viszonylag korán ráérzett az idősellátáshoz kapcsolódó képzésfejlesztés lehetőségeire és fontosságára). A modellváltást követően a Bárczin egy rövid ideig kihelyezett tagozaton folyt még a szociálisszervező-képzés, a szociálismunkás-képzésben pedig jelen volt egy „előszakosodás” az idősellátáshoz kapcsolódva is, amely tartalmában folyamatosan szűkült, majd a képzési reformok során néhány tárgynak az alapképzésbe olvasztásával elhalt. E változások kapcsán talán túl sarkos megfogalmazásnak tünhet annak állítása, hogy a szociálisszervező-képzés megszűnésével egy képzési vákuum keletkezett az idősellátás terén, miközben a hazai felsőoktatás gyakorlatilag „elengedte”, periferikus helyzetbe sodorta ezt a képzési területet, aminek a következő években jelentős következményei voltak.

\section{Néhány megjegyzés a kilencvenes évek változásai és a hosszú távú következmények kapcsán}

A rendszerváltást követően a szociális ellátórendszer átalakulása terén a szociális törvény és az 1/2000-s rendelet megjelenésével jelentős változásokat láthattunk, és bármennyire is voltak a jogszabályi keretek kapcsán kritikai észrevételek, összességében előrevitték az ellátórendszer fejlődését, és a szociális munkának mint professzionális segítő tevékenységnek elfogadását, még akkor is, ha a szociális ellátórendszer egésze szükös feltételek között, forráshiánnyal küszködve müködött, és differenciálatlansága, képzési háttereinek elégtelensége miatt törékennyé, sebezhetővé vált. Ez a helyzet az idősellátás vonatkozásában különösen jellemző volt.

Mindezek ellenére azt láthattuk, hogy ebben az időszakban a nehézségek ellenére a tartós bentlakást biztosító idősotthonokban megszilárdult a gondozási tevékenység folyamatszabályozású gyakorlata, javult a gondozó stábok minősége, képzettségi szintje, és a gondozási dokumentáció mentén követhetővé váltak a gondozás tartalmi jellemzői is. Megszilárdult a gondozásmenedzsment egy magasabb szintű szakmai felkészültség mellett (ld.: intézményvezető, intézményi főnővér, részlegvezető nővérek, orvosi-szakorvosi háttér biztosítása, gyógytornász, masszőr alkalmazása, szorosabb együttműködés a pénzügyigazdasági és müszaki stábokkal). E korszak jelentős teljesítménye pedig a segítő munka 
pszichoszociális területén megjelenő „mentálhigiénés csoport”-ok létrehozása volt, amely nagy arányban szociális munkásokra épült. Szintén fontos előrelépés volt a módszertani otthonok regionális létrehozása az akkreditált továbbképzési programokkal és módszertani fejlesztésekkel, amelyek, ha egyenetlen minőségben is, de lehetőséget kínáltak az intézményi stábok munkájának támogatására.

Az idősellátás fejlődésében nagy lehetőséget kínált a szociális alapellátáson belül az angolszász típusú „home care” programokhoz kapcsolódó ellátás fejlesztési kísérletek kezdeményezése. Ennek nyomán épült be a hazai idősellátásba a házi segítségnyújtás mint bővülő ellátási forma. A megvalósuló program, egybevetve a brit közösségi gondozással, amely a „kenti közösségi projekt” nyomán elemeiben már tartalmazta a modern gondozásmenedzsment szemléletét és gyakorlatát (ld.: Challis, Davies 1986), sajnálatos módon a sokat vitatott korai „case management”-modellek felé közelítve, és azok egy redukált változatát megvalósítva, egy szűkre szabott szolgáltatási gyakorlatot épített fel.

A házi segítségnyújtás és az idősek klubjaira épülő nappali ellátás hazai rendszerének elemzése és kritikája, túllépve e jelen tanulmány keretein egy másik tanulmány tárgya lehetne. Itt most azt emelném ki, hogy minden erőfeszítése ellenére a hazai idősellátás alapvetően bentlakásos otthon centrikus rendszer maradt egy szűkre szabott, redukált alapellátás mellett. Elmondható az, hogy elmaradt az idősellátás átalakulásához szükséges szemléletváltás és differenciált ellátásfejlesztés, valamint az a forrásallokáció, amely a hosszú távú tartós gondozás („long term care”) korszerü rendszerének felépítését lehetővé tenné. A rendelkezésre álló szükös forrásokat jelentős részben felemésztette a bentlakásos otthoni idősellátás elöregedő, korszerütlen intézményhálózatának fenntartása. Az, hogy ez az intézményrendszer egyáltalán működni tudott és az ódon falak között a gondozó stábok a napi nehézségek ellenére helytálltak, az nagyban köszönhető volt az intézményvezetésben meghatározó szerepet játszó szociális szervezők elkötelezettségének, józan praktikumának és túlélőképességének.

Miközben időnként láttunk erőfeszítéseket az idősellátás korszerüsítésére, és több kísérlet történt módszertani fejlesztésekre, újra és újra az volt tapasztalható, hogy e kezdeményezések kezdeti lendülete elfogyott és sok innovatív anyag íróasztalok fiókjaiban süllyedt el. Ha ennek okait próbáljuk megérteni, akkor vissza kell utalnunk arra, hogy az évek során valójában alig jöttek létre az elméleti hátterek megerősítését szolgáló kutatások és módszertani fejlesztéseket szolgáló, hosszú távra építkező szakmai mühelyek, és a felsőoktatási intézmények aktív 
partnersége is csak kismértékben volt jelen. Ha valaki csak kicsit is ismeri a gerontológia és idősellátás nemzetközi fejlődését, átfogó programjait, pontosan tudhatja azt, hogy a nagy longitudinális kutatások és a jól ismert stabil szellemi mühelyek szerepe a felsőoktatási kutatóhelyek részvételével együtt meghatározó volt e terület fejlődésében. Ma az látható, hogy a hazai idősellátás terén az elmulasztott lehetőségeket egyre nehezebb pótolni, és a demográfiai nyomások mentén sodródva olyan kihívások keletkeztek, amelyek az ellátási kapacitások növelési kényszere mentén a nagy bentlakásos otthonok fenntartása és bővítése irányába vitte tovább a hazai idősellátást, és ennek csapdájába esve egyre inkább megnehezül az átalakítás, miközben szembesülhetünk azzal, hogy a nagy intézmények nem képesek a szükséges szakmai létszámokat, minőséget biztosítani, és a működő képességhez szükséges stabilitást megőrizni. Ennek kapcsán utalnék Tom Kitwoodnak, a személyközpontú gondozás kialakításában úttörő szerepet játszó neves szakembernek „A demencia újragondolása” címü meghatározó jelentőségü munkájában írt soraira is, amelyekben kiemeli azt, hogy a centralizált nagy intézmények a maguk bürokratizált, túlkontrollált müködésével nem alkalmasak egy személyközpontú gondozási kultúra felépítésére (Kitwood 1997). Fontos látni azt is, hogy Kitwood életmúvének továbbvitelében a Bradfordi Egyetem ma már nemzetközi hírü demenciaműhelye jó példája annak, hogy a kutatás és gyakorlat szoros szövetsége nyomán kialakíthatók egy szakterület fejlődésében kulcsszerepet játszó innovatív szellemi központok, amelyek a képzések és módszertani fejlesztések terén meghatározó szerepet játszhatnak egy hosszú távú szakmai építkezés mentén. A hazai viszonyok közt ezzel szemben azt tapasztalhatjuk, hogy miközben vannak eredményeink a képzés és tananyagfejlesztés terén, és láthatunk innovatív erőfeszítéseket az idősellátás terepein is, ezek az erőfeszítések jórészt izoláltak maradnak, miközben az idősellátás egészének fejlődése kapcsán megtorpanásokat és visszalépéseket láthatunk.

Kitekintve a világba azt is láthatjuk, hogy a korszerű idősellátás fejlődése az időst otthonában megtartó és otthonközeli ellátások differenciált rendszerének, valamint az „emberléptékü” integrált intézményi keretek megteremtésének irányába halad, és kiemelt szerepet kap a gondozási kultúra alakítása a „gondozási partnerek” (az idős, a család és az intézményi stáb) közti viszonyok kapcsolatközpontú közös formálása mentén. Ez utóbbi kapcsán visszatekintve az idős otthonokban szerzett tapasztalataimra tisztelettel gondolok a gondozó stábok erőfeszítéseire, és volt tanítványainkra - köztük azokra a szociális szervezőkre, akik a nagy intézmények mostoha körülményei között próbáltak otthont teremteni az ott élő időseknek, és hidat építeni az idősellátásba érkező szociális munkások új generációja számára. 
A felvethető kritikai megjegyzések ellenére meg kell említenünk azokat a képzési és ellátásfejlesztési erőfeszítéseket is, amelyeket az elmúlt 10-15 évben az idősellátás terén láthattunk - így kiemelhető volt a salgótarjáni képzési központ jelentős szerepe Török Iván vezetésével a szociális szakemberek továbbképzése és posztgraduális képzési programjai kapcsán. Ezen belül kiemelkedett a Hegyesi Gábor által kezdeményezett és a nemzetközi együttmüködés talaján létrejött szociálismenedzser-képzés, amely az elsők között kínált posztgraduális képzési lehetőséget az idősellátás terén dolgozó szociális szervezőknek. Hasonlóan fontos volt az ,alkalmazott szociálgerontológia” szakirányú továbbképzési szak létrejötte, amely a nyíregyházi képzésben bontakozott ki és szilárdult meg, majd több képzőhelyen is beindult a már terepen lévő szakemberek posztgraduális képzésével. Fontos lépés volt az „egészségügyi szociálismunkás-képzés” megjelenése mesterszakon, amelyben képzési blokként megjelent az idősellátás témaköre (ez talán az első lépések egyike az „alkalmazott MA” programok kialakítása felé, amely keretében távlatban létrehozható egy önálló „gerontológiai szociális munka” szakirány MA-szinten, illeszkedve az angolszász MAprogramokban megjelenő szakosodási irányokhoz párhuzamosan az „advanced generalist” modellt képviselő MA-programokkal). Végül kiemelhető a Debreceni Egyetem Egészségügyi Karán létrejött Gerontológia Tanszék, amely a gerontológiai kutatások és egy „gerontológia MSc” program kialakításának bázisát képviselheti a jövőben.

Elmondható azonban az, hogy ezek az eredmények nehezen törik át az izoláció falait, alacsony szintü az információmegosztás és együttmüködés, és nincs átfogó képünk az innovatív kezdeményezésekről, miközben mindez nem tudja ellensúlyozni azt, hogy az idősellátás terén egy erős centralizáció és szabályozás nyomán egyre nagyobb szakadék keletkezik a korszerü idősellátás nemzetközi gyakorlata és a hazai ellátás színvonala között.

Visszatekintve a szociálisszervező-képzésre összességében elmondható, hogy fontos értéke volt az, hogy a mostoha ellátási körülmények között dolgozó tanítványai számára értékorientációjában és a segítés gyakorlatában a személyközpontú gondozás egy korai formájának elemeit hordozó intézményi kultúrát próbált közvetíteni egy gyakorlatközeli praktikus megközelítésben, miközben erősen épített a hallgatók terepről hozott tapasztalataira és kiemelten támaszkodott az ellátórendszer és képzőintézmény élő kapcsolatára. Fontos törekvése volt egy idősellátási szakirány tartalmi felépítése is. A képzésimodell-váltás nyomán e törekvések háttérbe szorultak, de potenciálisan lehetőség nyílt arra, hogy egy korszerü, differenciált képzés szülessen. Leegyszerüsítve mondhatnánk azt, hogy ezt a lehetőséget a szociálismunkás-képzés elszalasztotta, de átélve a szociális képzések és a 
szociális munka gyakorlatának hányatott sorsát és több évtizedes sodródását, méltányosabb a közös sors tanulságai nyomán azt megfogalmazni, hogy a képzésimodell-váltás hozadéka az a felismerés, hogy a hazai idősellátásnak a kiutat az igényes képzés, a szakirányok megerősítése és a módszertani fejlesztések, gyakorlati innovációk, valamint a képző-kutató intézmények és terepek szövetségében létrejövő szakmai mühelyek, a „felhasználói oldal” támogatása, érdekérvényesítő ereje, valamint a szakmai kultúra és a szakmai identitás megerősítése kínálhatja. A hazai idősellátás fejlődéséhez ez az út megkerülhetetlen.

\section{Irodalomjegyzék}

CHALliS, D., DAVIES, B. (1986): Case Management in Community Care. Gower Publ. Co., Brookfield.

HEGYESI G. (2018): Emlékek a szociális munka születésének társadalomtörténetéröl. Párbeszéd szociális munka folyóirat, 5 (4). 2.

HUN N. (1972): Bevezetés a gerontológiába. (Második kiadás 1978). Medicina Kiadó, Budapest. 1972. / másidik kiadás 1978./

KITWOOD, T. (1997): Dementia Reconsidered: The Person Comes First. Open University Press, Buckingham.

SÁHÓ E. (1993): Szociális gondozás. Szociális Munka Alapítvány, Budapest.

VILLÁNYI P. (1978): Szociálgerontológia. Szociális Munka Alapítvány, Budapest. 